\title{
Pacific Northwest Laboratory ALARA Report for CY 1990
}

\author{
G. M. Ceffalo \\ C. L. Oxley \\ P. A. Wright
}

May 1992

Prepared for the U.S. Department of Energy under Contract DE-AC06-76RLO 1830

Pacif $\approx$ Northwest Laboratory Operated for the U.S. Department of Energy by Battelle Memorial Institute 


\title{
DISCL.AIMER
}

This report was prepared as an account of work sponsored by an agency of the United States Government. Neither the United States Government nor any agency thereof, nor Battelle Memorial Institute, nor any of their employees, makes any warranty, expressed or implied, or assumes any legal liability or responsibility for the accuracy, completeness, or usefulness of any information, apparatus, product, or process disclosed, or represents that its use would not infringe privately owned rights. Reference herein to any specific commercial product, process, or service by trade name, trademark, manufacturer, or otherwise does not necessarily constitute or imply its endorsement, recommendation, or favoring by the United States Government or any agency thereof, or Battelle Memmrial Institute. The views and opinions of authors expressed herein do not necessarily state or reflect those of the United States Governinent or any agency thereof.

\author{
PACIFIC NORTHWEST LABORATORY \\ operated by \\ BATTELLE MEMORIAL INSTITUTE \\ for the \\ UNITED STATES DEPARTMENT OF ENERCY \\ under Contract DE-AC06-76RLO 1830
}

Printed in the United States of America

Available to DOE and DOE contractors from the

Office of Scientific and Technical Information, P.O. Box 62, Oak Ridge, TN 37831; prices available from (615) 576-8401. FTS 626-8401.

Available to the public from the National Technical Information Service, U.S. Department of Commerce, 52135 Port Royal Rd., Springfield, VA 22161. 
PNL- -8075

DE92 014240

PACIFIC NORTHWEST LABORATORY

ALARA REPORT FOR CY 1990

Prepared by Laboratory Safety

May 1992

Prepared for

the U.S. Department of Energy

under Contract DE-ACO6-76RLO 1830

Pacific Northwest Laboratory

Richland, Washington 99352

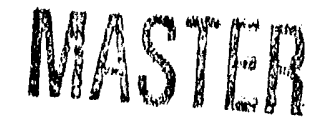




\section{SUMMARY}

This report provides summary results of the CY 1990 ALARA Program at the Pacific Northwest Laboratory. (a) Information has been included regarding whole-body exposures to radiation, skin contaminations, and the nonradiological ALARA program.

The collective whole-body radiation dose to employees during 1990 was 0.68 person-sievert (68 person-rem). (b) This dose was $85 \%$ of the projected dose of 0.80 person-sievert ( 80 person-rem). There were three PNL employees whose doses were extrapolated to exceed 0.02 sievert ( 2 rem) during the year, but no workers actually exceeded 0.02 sievert (2 rem) by the end of CY-1990.

There were 31 reported cases of skin contamination for PNL employees during 1989. This number is $78 \%$ of the projected total of 40 cases. The majority of these cases (48\%) occurred at the 324 facility.

Progress was made on implementing ALARA (as low as reasonably achievable) practices through ALARA goals developed and carried out by the research centers.

The injury accident rates indicate that staff members and the public have been well protected from unacceptable exposure to nonradiological hazards. The motor vehicle accident and loss rates were greatly improved due to employees' abilities to avoid accidents, with rates below U.S. Department of Energy (DOE) averages. There were no PNL fires in 1990 that resulted in damage. Starting in 1988, the industrial health and safety section began publishing accident data and rates for each center, allowing management to monitor safety performance parameters in their organization.

(a) The Pacific Northwest Laboratory is operated by Batielle Memorial Institute for the U.S. Department of Energy.

(b) The total whole-body dose is based only on onsite exposure; however, to make this report as useful as possible to PNL staff, all other data, discussions, conclusions, etc. in this report include both onsite and offsite exposure. 


\section{CONTENTS}

SUMMARY ................................

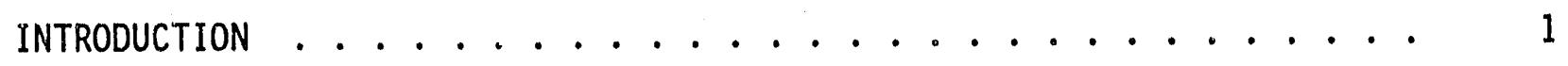

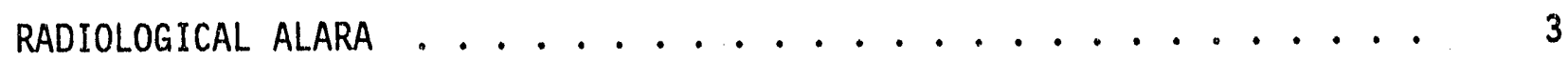

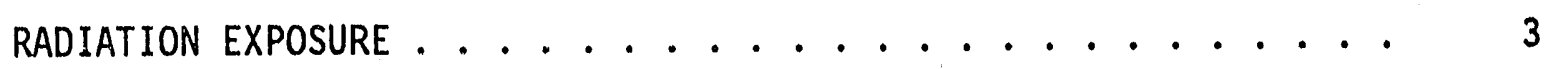

Exposure Trends ..................... 3

Quarterly Exposure Evaluations ........... 6

SKIN CONTAMINATION . . . . . . . . . . . . . . 7

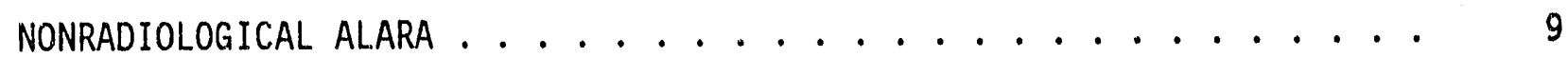

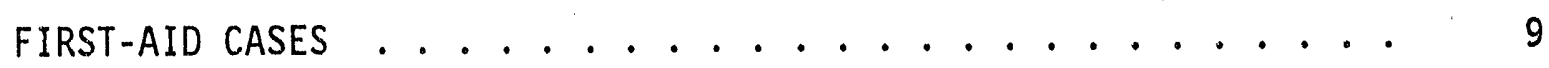

RECORDABLE INJURIES AND ILLNESSES .................. 9

LOST WORKDAY INJURIES . . . . . . . . . . . . . . . . 9

MOTOR VEHICLE ACCIDENTS ..................... 11

PROPERTY DAMAGE AND FIRES ................. . . . 13

ACCIDENT INVESTIGATION ....................... 13

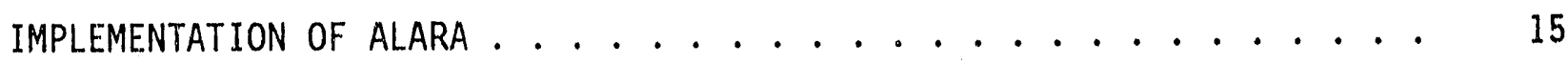

APPENDIX A - STATUS OF CY 1989 ALARA GOALS . . . . . . . . . A.1

APPENDIX B - RADIOLOGICAL ALARA GOALS FOR CY $1990 \ldots \ldots$. . . . . B.1

APPENDIX C - PROJECTIONS FOR CY $1990 \ldots \ldots \ldots$. . . . . . . . .

APPENDIX D - SKIN CONTAMINATION CASES DURING CY $1989 \ldots \ldots$. . . . . 


\section{FIGURES}

1. Dose Distribution for $\mathrm{CY} 1990 \ldots \ldots$. . . . . . . . . . 3

2 Annual Collective Whole-Body Dose for the Last 10 Years ...... 4

3 Collective Whole-Body Dose for 1987, 1988, and 1989 for the 10 Highest Departments . . . . . . . . . . . 5

4 Annual Incidence of Skin Contaminations from 1986 through $1990 \ldots 7$

5 Annual Totals of Skin Contamination Cases by Facility ...... 8

6 PNL Recordable Injury Incidence Rate ............. 10

7 PNL Lost Workday Case Incidence Rate ............. 10

8 PNL Lost Workday Incidence Rate . . . . . . . . . . . . . 11

9 PNL Motor Vehicle Accidents Per Million Miles . . . . . . . 12

10 PNL Motor Vehicle Loss Rate . . . . . . . . . . . . . . 12

11 PNL Property Damage Loss Rate . . . . . . . . . . . . 13

12 PNL Fire Loss Rate . . . . . . . . . . . . . . . . . 14

\section{TABLES}

1 Number of Staff Members Whose Extrapolated Year-End

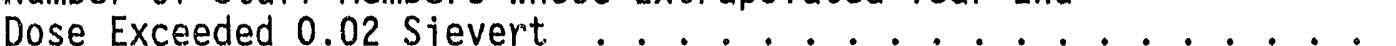




\section{INTRODUCTION}

The concept of maintaining exposures to radiation as low as possible (ALAP) was first introduced formally in 1954 by the National Committee on Radiation Protection. DOE 5480.11, "Radiation Protection for Occupationa 7 Workers," establishes requirements for DOE contractor ALARA programs and references Health Physics Manual of Good Practices for Reducing Radiation Exposures to Levels that are As Low As Reasonably Achievable (ALARA), which describes possible elements of ALARA programs. Section 10.0 of PNL-MA-6, "Radiation Protection, " provides information on PNL's ALARA program. The purpose of this report is to summarize and document activities, accomplishments and results of safety parameters involved in the ALARA Program during CY 1990.

At PNL, appiying the ALARA philosophy is not limited to nuclear hazards; PNL applies the ALARA concept to a wide variety of hazards, including exposure to hazardous chemicals and physical hazards (lasers, noise, etc.). Chemical exposure is kept ALARA by substituting less hazardous chemicals, using engineering controls such as ventilation or containment, and using administrative controls and personal protective equipment. Reduced exposure to physical hazards such as lasers or rotating equipment is accomplished by separating people from the hazard through the use of timing, distancing or shielding/ guarding.

The ALARA Program is administered by the Occupational and Radiological Safety Section of the Laboratory Safety Department. The research organizations develop ALARA goals; the ALARA coordinator tracks their progress throughout the year. The goals and their status are presented in Appendix $A$; Appendix $B$ contains the radiological and nonradiological goals for CY 1991. 


\section{RADIOLOGICAL ALARA}

This section summarizes the portion of the ALARA Program that deals with radiological concerns. It includes information on radiation doses and skin contaminations and identifies the organizations with the highest doses.

\section{RADIATION EXPOSURE}

In CY 1990 a total of 0.68 person-sievert (68 person-rem) was received by staff members monitored for compliance with DOE 5480.11 (i.e., multipurpose dosimeter wearers). At the beginning of the year, 0.80 person-sievert ( 80 person-rem) was projected based on planned activities, primarily those in the 324 and 325 facilities.

\section{Exposure Trends}

The distribution of doses among staff members monitored for compliance with DOE 5480.11 (multipurpose dosimeter wearers), is shown in Figure 1. The most frequent1y occurring dose for staff members during 1990 was 0 mi11isievert (0 millirem). The average dose for this group during 1990 was $0.44 \mathrm{mi11}$ isievert (44 millirem), compared to 0.6 millisievert (60 millirem) in 1989. Figure 2 shows the yearly trend in collective whole-body dose for PNL.

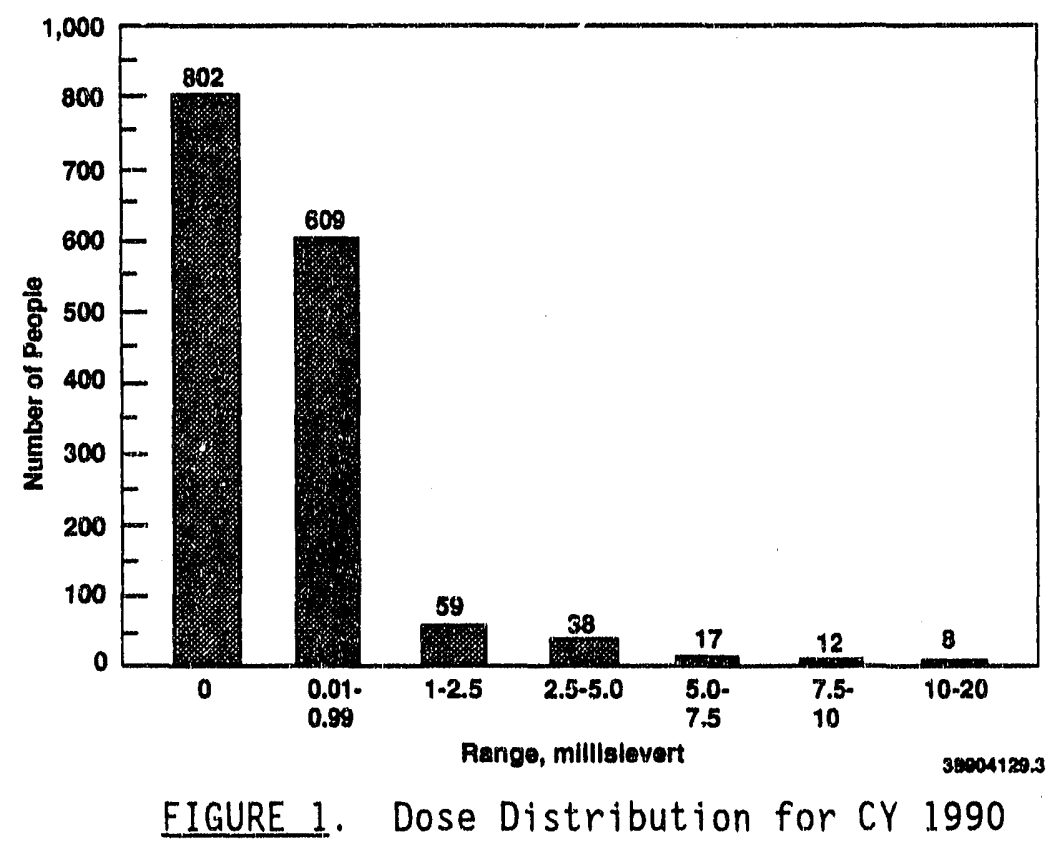




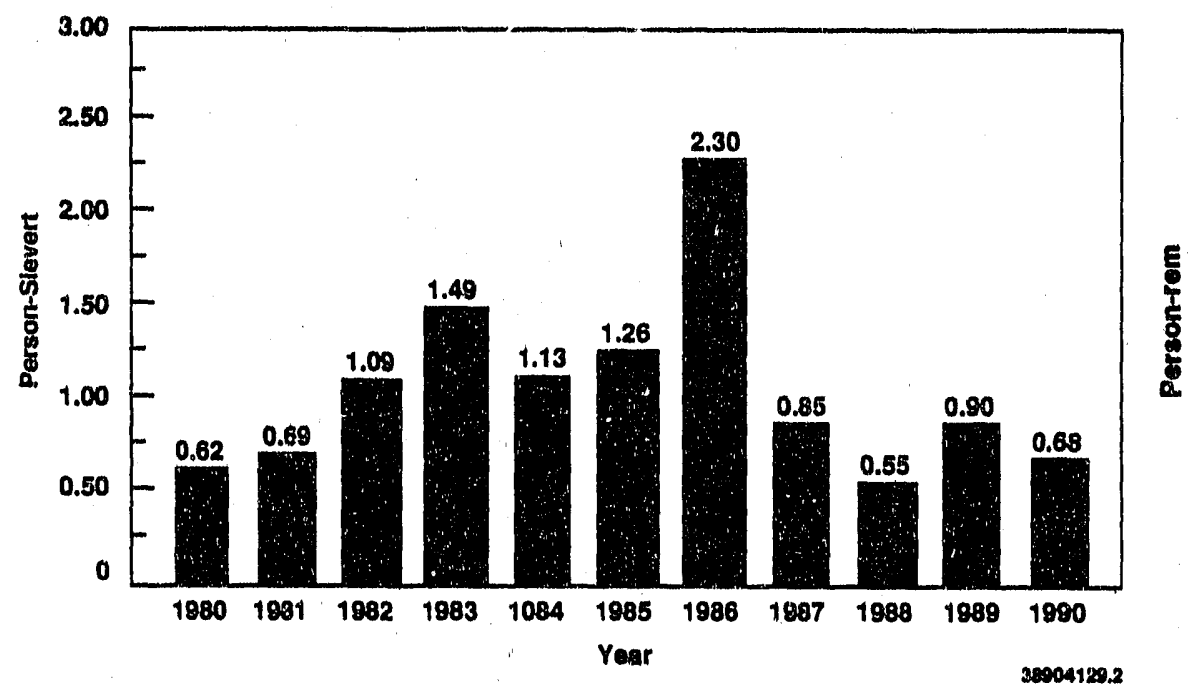

EIGURE 2. Annual Collective Whole-Body Dose for the Last 10 Years

The figure illustrates the dependence of collective dose on the major programs. The dose maximum in 1986 was related to the destructive examination phase of the steam generator project. The collective dose for PNL is expected to remain below 1 person-sievert (100 person-rem) over the next several years, unless significant program changes occur.

Figure 3 shows the yearly trend in total collective whole-body dose incurred by the five centers with the highest collective whole-body doses for the last 3 years. (a) Facilities and Operations accounted for approximately $32 \%$ of the total CY 1990 PNL collective whole-body dose. The Material and Chemical Sciences, Reactor Technology and Waste Technology Centers accounted for the majority of the balance of the total dose, incurring approximately $24 \%, 17 \%$ and $14 \%$ respectively.

A1I of the centers, except for Facilities and Operations and Health Physics, significantly decreased their doses relative to their 1989 totals. Much of this improvement was due to the fact that a major 1989 project (the

(a) As a result of reorganizations and the reassignment of staff members, il was difficult to compare annual doses assigned to organizations with complete accuracy. These data do, however, provide a fairly good picture of the major doses received by each organization. 


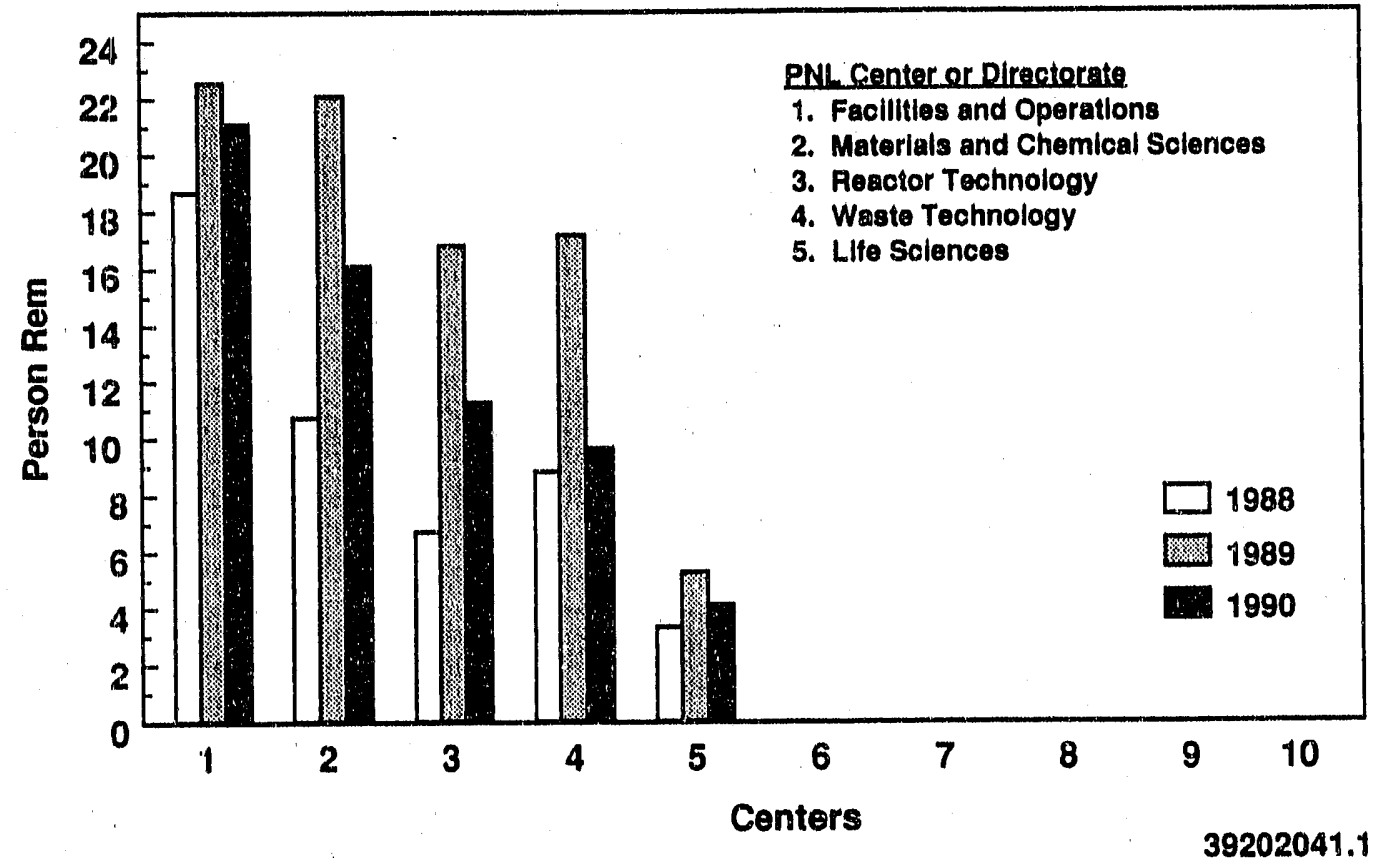

FIGURE 3. Collective Whole-Body Dose for 1988, 1989, and 1990 for the 10 Highest Departments

single-she11-waste characterization) which caused significant evenly distributed doses was completed. Other factors that may have improved the dose totals were the accomplishment of many ALARA goals (see Appendix A, "Status of CY 1990 ALARA Goals"), conducting pre-job ALARA meetings and the relative total work load of the centers. Departments in the Facilities and Operations Center as well as Health Physics have remained consistent at their present dose levels over the past few years, mostly due to the unavridable routine requirements of their jobs: performing radiation protection duties, detector and dosimeter calibrations, and facilities and equipment maintenance.

The departments incurring the highest doses in Facilities and Operations during 1990 were Laboratory Safety and 300 Area Crafts Services; approximate1y $13 \%$ and $14 \%$ of the PNL total, respectively. Recommendations were made that these departments develop annual ALARA goals. The Analytical Chemistry Laboratory of Materials and Chemical Sciences had 15\% of the total number of exposures. Post-Irradiation Examination Services of Reactor Technology received 11\% of the total, while Waste Process Engineering of Waste Technology accourted for $9 \%$ of the total. The majority of the doses for all of these 
departments were attributed to work in the 324 and 325 Buildings. As with their respective centers, most departments showed significant decreases in total doses during 1990.

Observing the centers' and departments' trends of collective dose totals over the years indicates that the levels are directly related to the number of projects involving work with radioactive materials. The number of projects involving radiation work and the relative amount of this type of work load have been historically variable, making it somewhat difficult to adjust or weight the collective doses for comparison of different years. Personnel and organizational groups may be reassigned to other jobs or organizational groups continuously throughout the year, making it relatively difficult to accurately assign doses to specific projects and work. Considering these obstacles involved in accurate trend analysis, the 1990 collective dose totals for PNL have shown typical or expected values in comparing with the recent years' totals (after 1986).

\section{Quarterly Exposure Evaluations}

Procedures for identification, tracking and evaluation of job tasks of staff members receiving potentially excessive whole-body and/or extremity doses remained in place in 1990. Three staff members exceeded the criteria for special evaluations. Supervisors of staff members with doses that indicate potential to exceed annual limits received a quarterly exposure evaluation request (and form) for each staff member with a high dose. The supervisor evaluates the tasks being performed by the individual(s), and records pertinent information on the exposure evaluation form so that ALARA practices can be implemented wherever possible. Radiological Engineering reviews the supervisor's evaluation and initiates follow-up actions as appropriate. The whole-body and extremity quarterly doses used as critiria for evaluation are those values that extrapolate to year-end doses of 0.02 sievert (2 rem) for the whole-body and 0.30 sievert $(30$ rem) for the extremities. As shown in Table 1, eight PNL staff members exceeded the criteria for evaluation during 1989. In 1990, three individuals exceeded the limit in first quarter; however, no one exceeded the limit for the year. 
IABLE 1. Number of Staff Members Whose Extrapolated

Year-End Dose Exceeded 0.02 Sievert

$\begin{array}{ccc}\text { Quarter } & \text { cy } 89 & \text { cy } 90 \\ 1 \text { st } & 6 & 3 \\ \text { 2nd } & 1 & 0 \\ \text { 3rd } & 1 & 0 \\ 4 \text { th } & 0 & 0\end{array}$

\section{SKIN CONTAMINATION}

In CY 1990, PNL had a total of 31 cases of skin contamination (see Appendix D). Figure 4 shows the historical trend of yearly skin contaminations for the period 1986-1990. Figure 5 provides a breakdown of skin contamination cases in 1990 by facility since 1986. Most of these cases (14) occurred in the 324 facility. At the beginning of the year, 30 cases were projected based on planned activities.

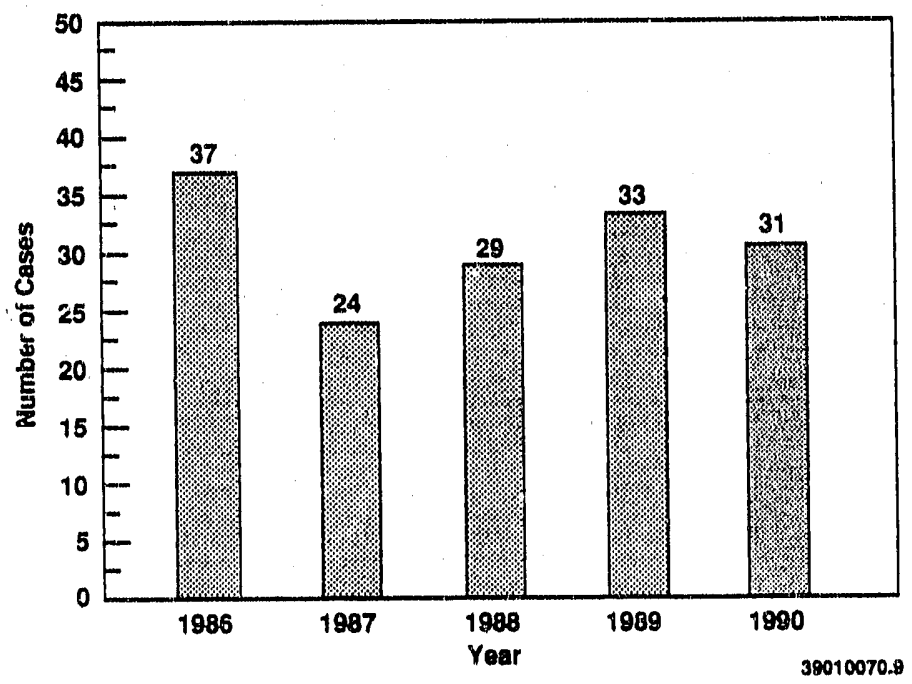

FIGURE 4. Annual Incidence of Skin Contaminations from 1986 through 1990 


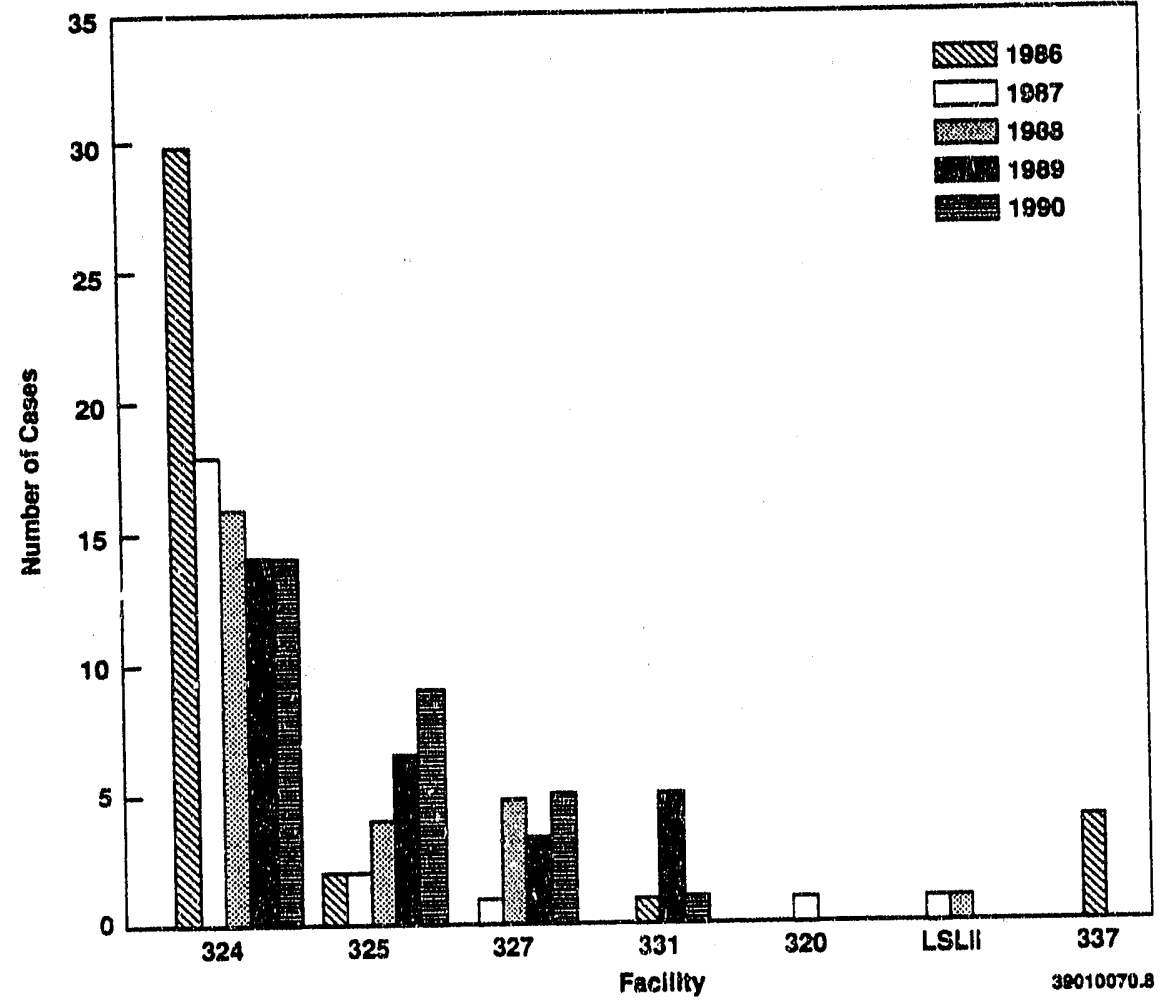

FigURE 5. Annual Totals of Skin Contamination Cases by Facility 


\section{NONRADIOLOGICAL ALARA}

During CY 1990, the Laboratory had an average of 3326 ful1-time staff memhers who worked approximately 3-4 million hours on PNL-related programs. This section discusses the nonradiological safety performance of staff members for $C Y 1990$.

\section{FIRST-AID CASES}

The Laboratory Safety Department investigated 145 first-aid cases during CY 1990. Each reported occupational injury or iliness was investigated by Laboratory Safety staff members, and corrective actions were recommended to line management as appropriate to prevent recurrence. Criteria defined $b$ the U.S. Departiment of Energy (DOE) or the State of Washington are used to classify the injury or $i 17$ ness and determine required documentation.

\section{RECURDABLE INJURIES AND ILLNESSES}

Occupational injuries are considered recordable if they are severe enough to require medical attention beyond first aid (e.g., prescription medication, sutures, treatment of broken bones, lost workday cases, etc.). A11 occupational 11 inesses are considered recordable. Recordable injuries and i17nesses are investigated jointly by the Laboratory Safety Department and line management. During CY 1990, staff members incurred 35 recordable injuries. This number resulted in a recordable injury incidence rate of 2.05 recordable injuries or 171 nesses per 200,000 work hours. The 1990 rate nearly doubled from that of 1989 , but the increase was primarily due to a change in the mandatory criteria for determining the recordability of injuries and 111 nesses. This rate is compared to past PNL rates and to DOE's Richland Operations office (DOE-RL) in Figure 6.

\section{LOST WORKDAY INJURIES}

An injury or illness is considered a lost workday case if the staff member misses an entire, regularly scheduled, work shift due to an occupational accident. These injuries are considered more serious than most other recordable injuries since the consequences include significant lost time. 
Staff members sustained 19 lost workday cases during 1990, which resulted in a lost workday case incidence rate of 1.11 lost workday cases per 200,000 work hours. This rate is compared to past PNL rates and to DOE-RL averages in Figure 7 .

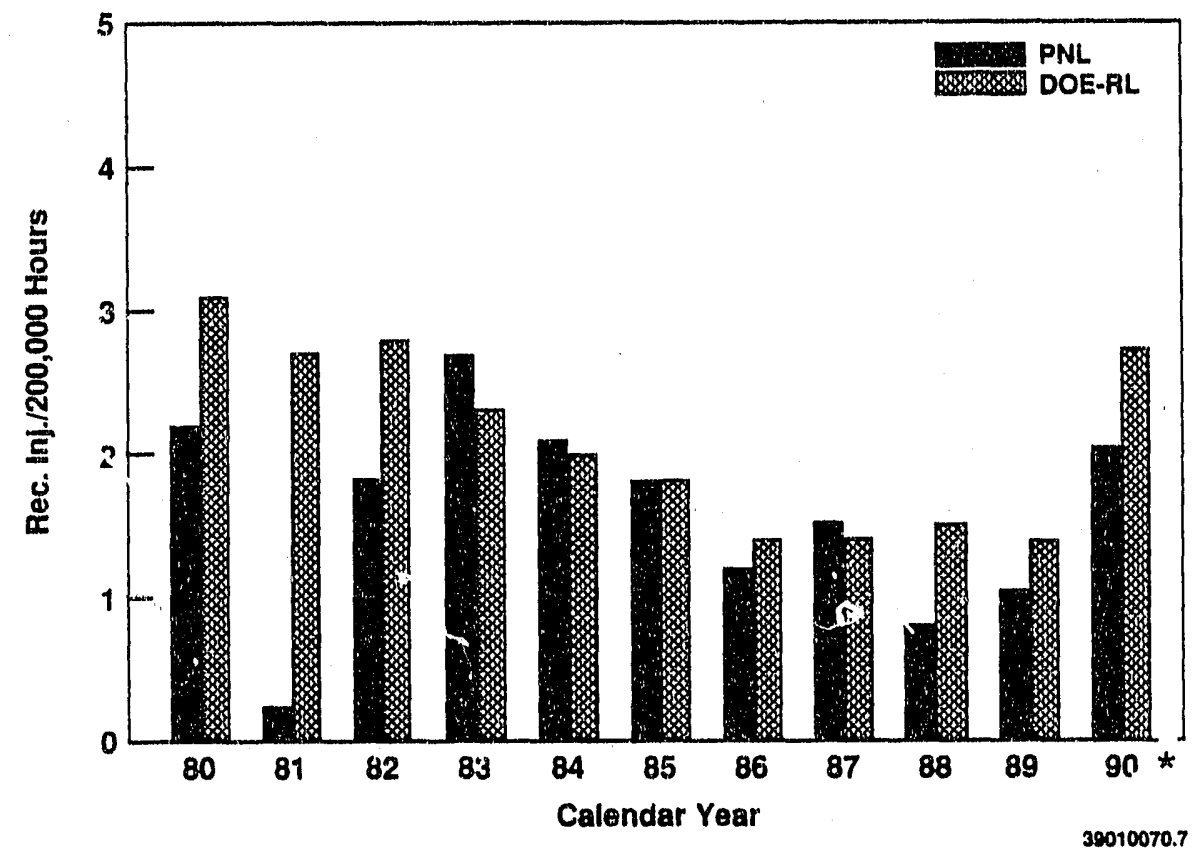

FIGURE 6. PNL Recordable Injury Incidence Rate

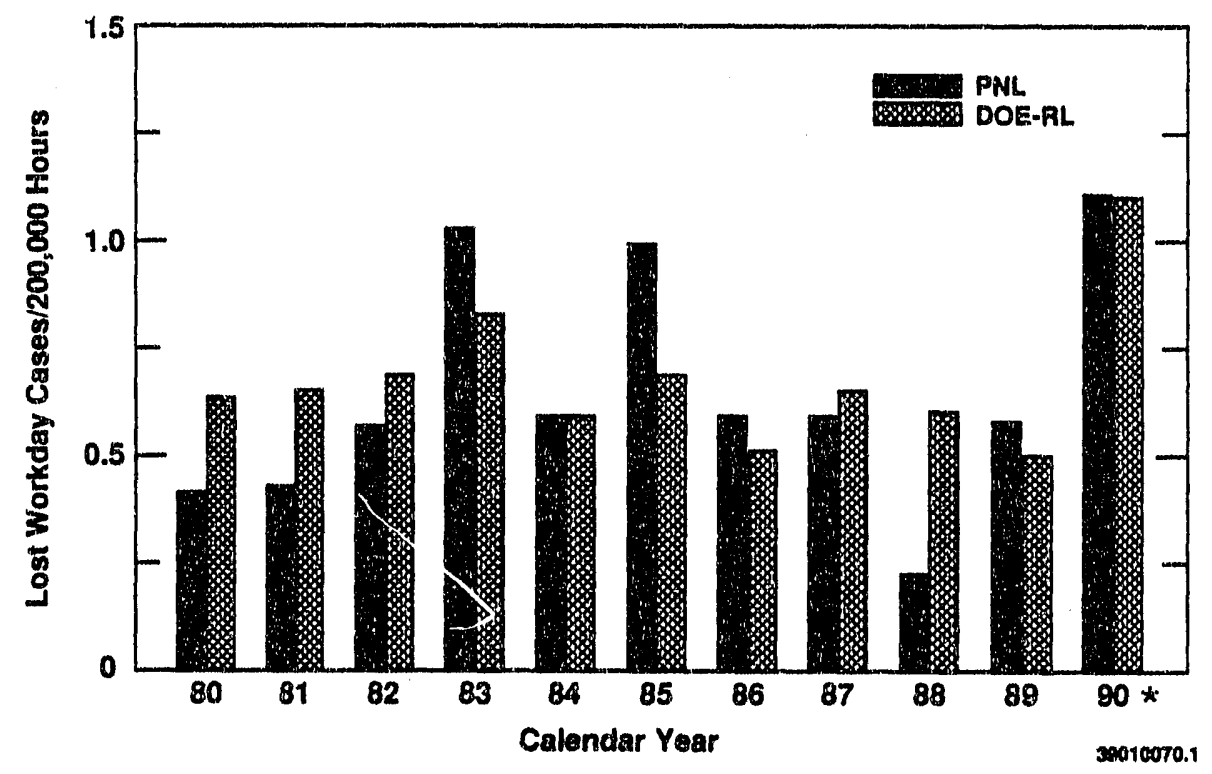

FIGURE 7. PNL Lost Workday Case Incidence Rate 
The 19 lost workday cases resulted in 72 lost workdays and 59 days of work restriction. These lost and restricted workdays resulted in a lost workday incidence rate of 7.67 lost workdays per 200,000 work hours. This rate is compared to past PNL rates and to DOE-RL averages in Figure 8.

\section{MOTOR VEHICLE ACCIDENTS}

Staff members drove government vehicles approximately 0.83 million miles without an accident during 1990. PNL's motor vehicle accident rate for 1990 was 0 accidents per inillion miles, as compared to 6.67 accidents per million miles in 1989. These rates are compared to past PNL rates and to DOE-RL averages in Figure 9.

The motor vehicle loss rate for 1990 of $\$ 0.00$ per thousand miles compares to $\$ 14.51$ per thousand miles in 1989 . This rate is compared to past PNL and DOE-RL rates in Figure 10.

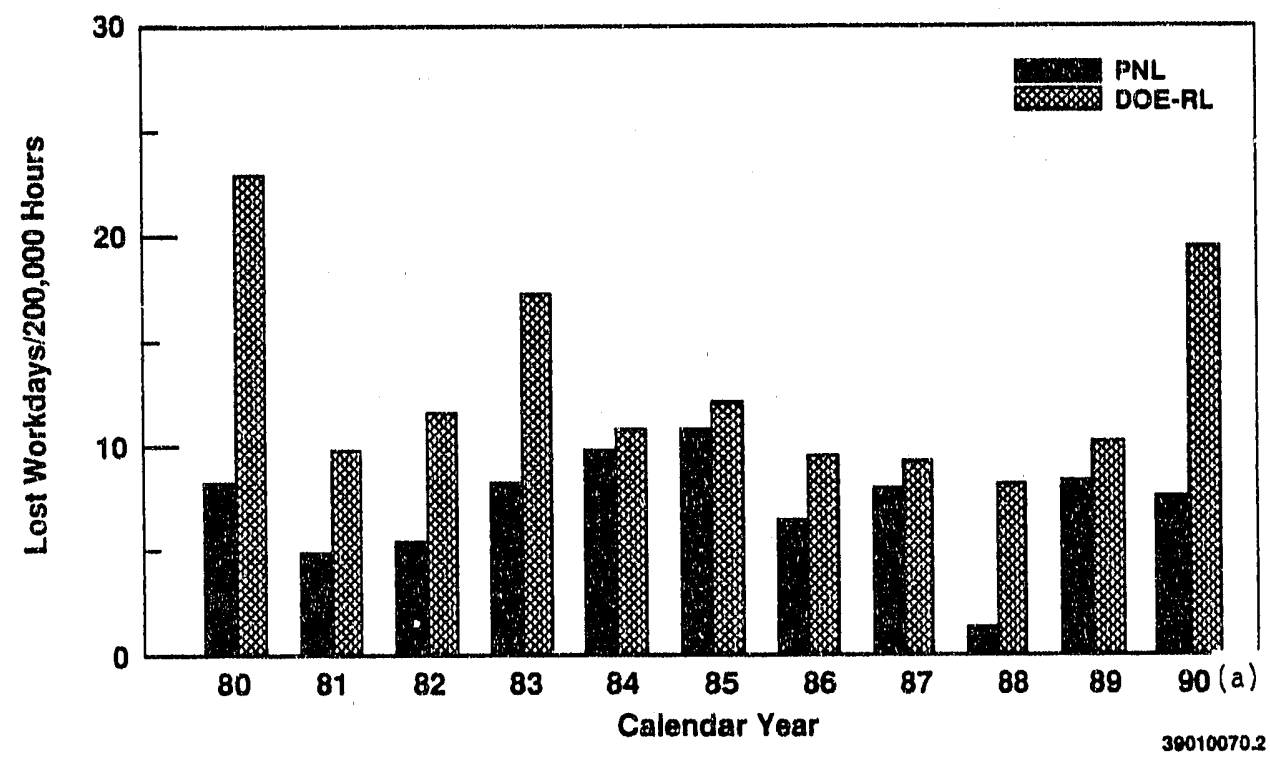

(a) In 1990, PNL began using BLS criteria, resulting in slightly higher numbers of recordable occurrences.

FIGURE 8. PNL Lost Workday Incidenc:e Rate 


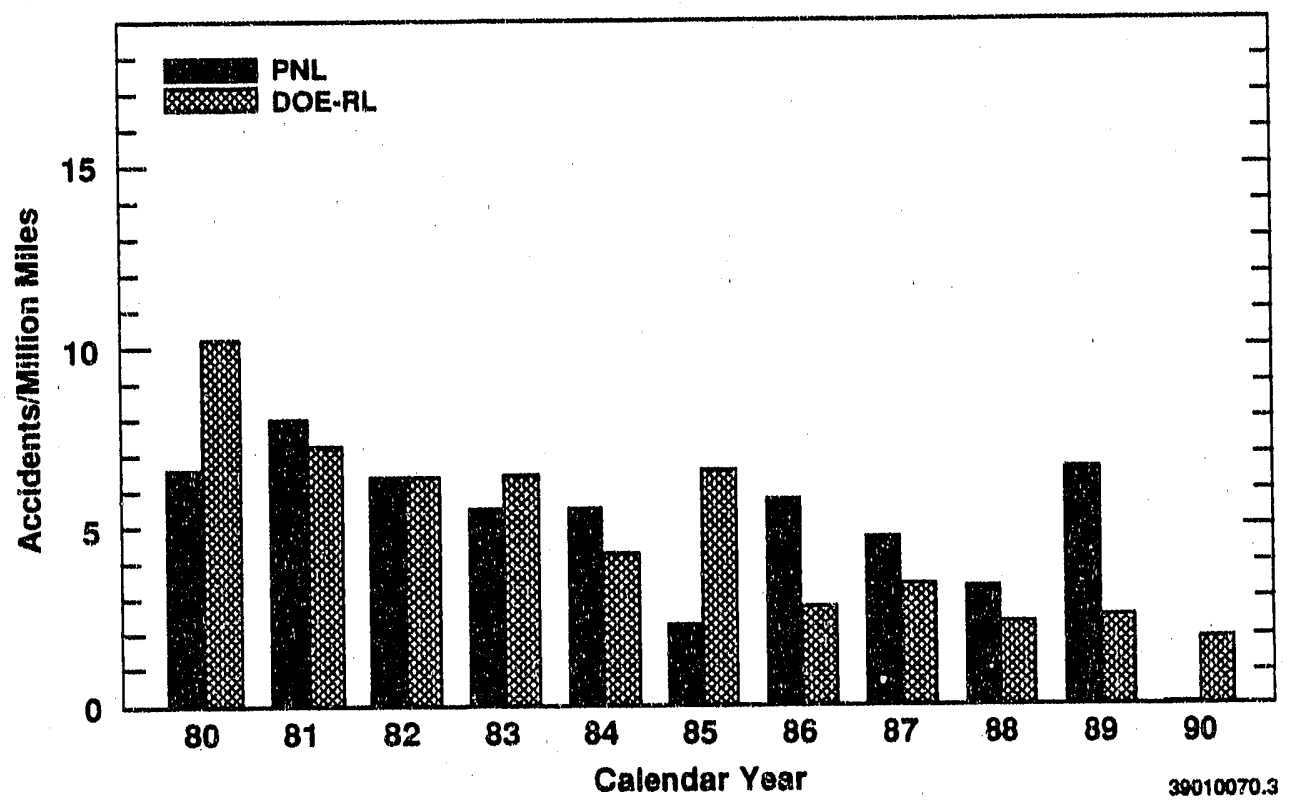

FIGURE 9. PNL Motor Vehicle Accidents Per Million Miles

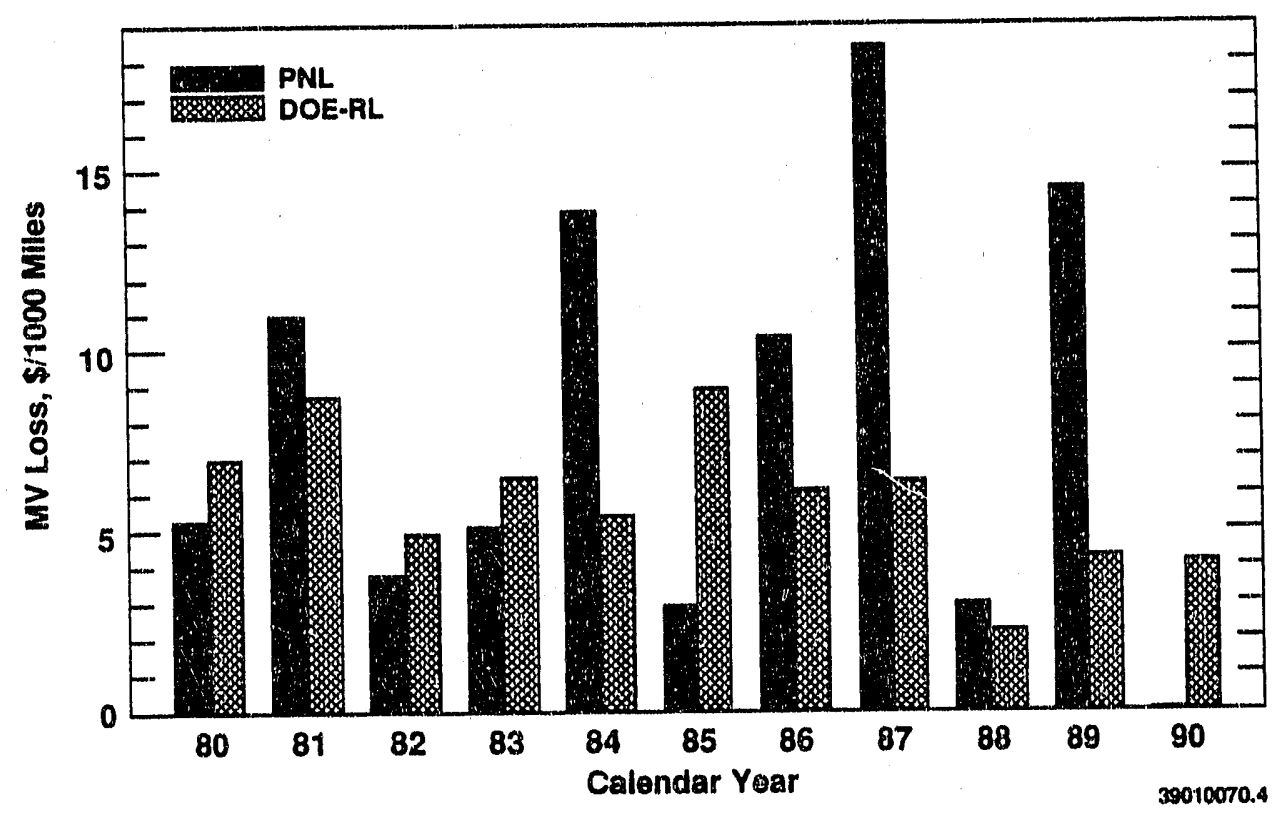

FIGURE 10. PNL Motor Venicle Loss Rate 


\section{PROPERTY DAMAGE AND FIRES}

During $C Y$ 1990, PNL work resulted in one nonfire property-10ss accident and $\$ 3,300$ in losses. This is a property damage rate of 0.09 for CY 1990 . This rate is compared to other PNL property-loss rates and to DOE-RL averages in Figure 11.

There were no fires damaging PNL property in 1990, resulting in a fireloss rate of 0 . This rate is compared to other PNL fire-loss rates and to DOE averages in Figure 12.

\section{ACCIDENT INVESTIGATION}

All accidents, injuries, illnesses, motor vehicle accidents, fires, and property damage are investigated by Laboratory Safety. Accidents with serious consequences are investigated and documented in detail. Management involvement is required in the response and investigation of accidents and in the establishment and implementation of corrective action. These activities ensure that appropriate actions are taken to prevent recurrence of the accident, and they demonstrate PNL's commitment to providing a safe and healthful workplace.

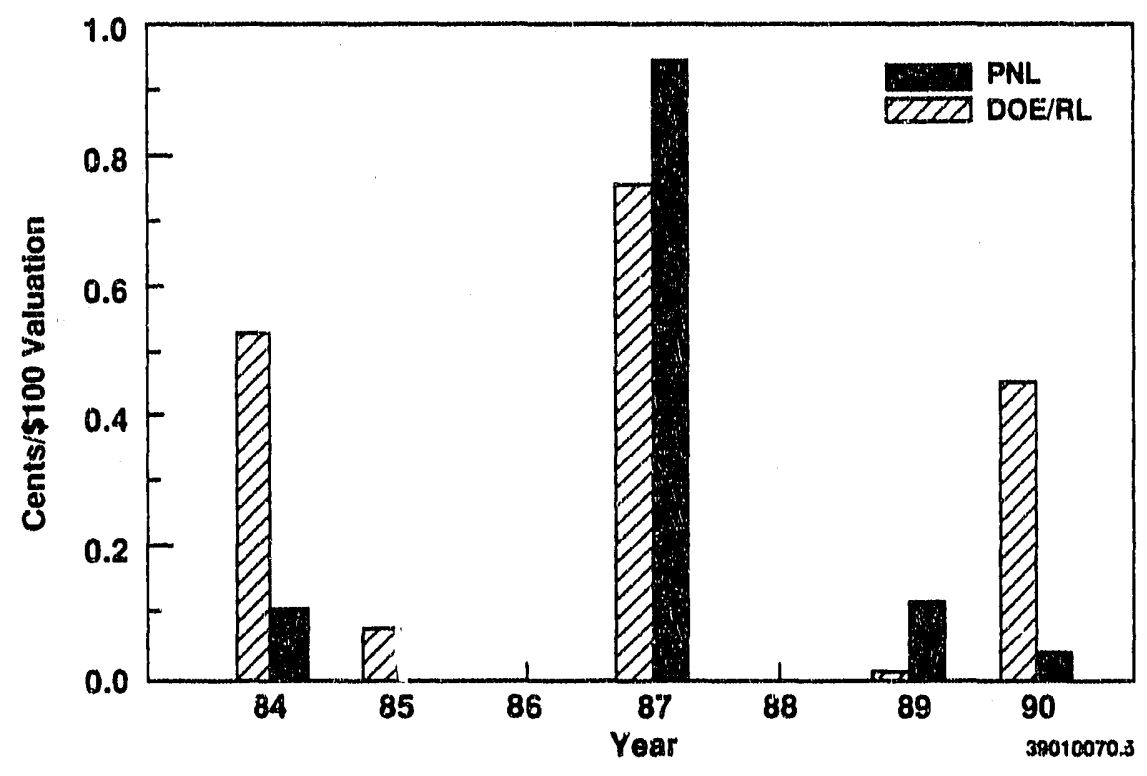

FIGURE 11. PNL Property Damage Loss Rate 


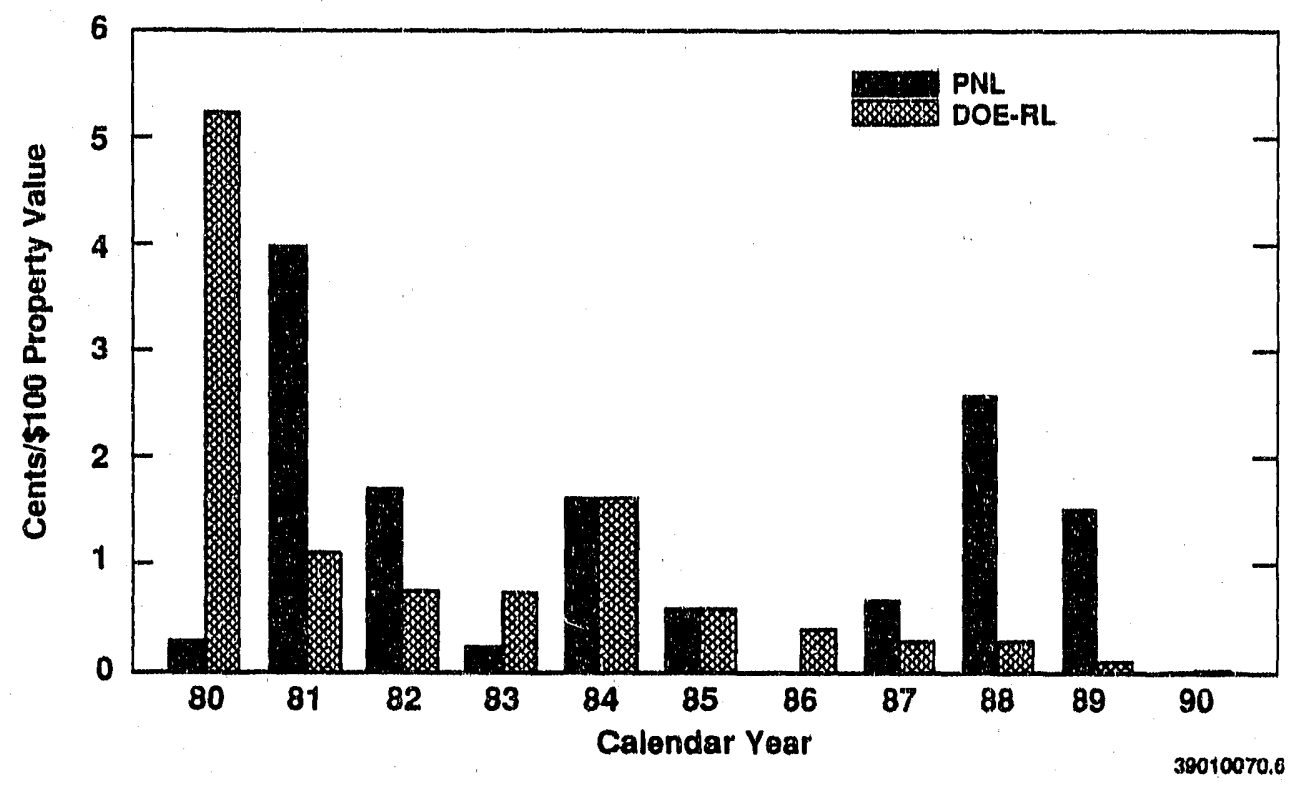

FIGURE 12. PNL Fire Loss Rate 


\section{IMPLEMENTATION OF ALARA}

Progress was made during 1990 on the implementation of ALARA as evidenced by the development and achievement of ALARA goals by the operational organizations. The final status of the 1990 ALARA goals is given in Apperdix $A$. The radiological ALARA goals for 1991 are given in Appendix $B$.

Audits of radiological ALARA requirements are conducted routinely for specific facilities with significant potential for causing exposures. These ALARA audits are part of a comprehensive safety audit of the facility, designed to evaluate and improve total safety performance. In addition, the ALARA contest was continued in 1990 to increase the awareness of the ALARA philosophy among staff members. 
APPENDIX A

STATUS OF CY 1990 ALARA GOALS 
Waste Teohnology 324

Laboratory

Safety 324

Matertals and Chemical Sciences $396 \mathrm{~W}$
Goal

Establish a monthly reporting system for individual staff exposure rates.

Implement a Hot $\mathrm{Ce}$ ll Waste Disposal System for radioactive operations within the Waste Technology Center.

Monitor the RPT dose in the 324 facllity to determine which activities contribute the most dose. The dose versus activity data will be evaluated quarterly and methods will be evaluated for reduoing dose for those activities contributing the major poition of dose.

Develop disposal process for depleted uranium scrap and reduce inventory. Initiate disposal by $4 / 1 / 90$. Stay current with generation by $9 / 30 / 90$.

Relocate or dispose of ThO, located in Room 141 to reduce dose rate in Laboratory \#151. Completion by $7 / 1 / 9 \varnothing$.

Shield filters in Room 40 to reduce dose rate at front face of $325 \mathrm{~A}$ hot cells. Completion by $4 / 1 / 90$.

Reduce high background stored material in Lab 327.
Status

A request has been submitted to implement a system to provide the required exposure data. This system has been initlated. This goal is ounsidered oompleted.

The West inghouse HC-200 Cask/Disposal Lines system has been selected for implementation. Disposal lines and grout containers have been prooured and received. Planned implementation of the HN-200 Cook/Lines Disposal System is in May 1990. The ut 11 . zation of the HC-20 Cask/Disposal system is underway. The goal is considered completed.

RPT exposures wer'; monitored and the activities which contributed the most dose were ident if led. Improvements for reduoing dose are being develuped. The goal is considered complete.

Process developed; SDAR approved. Forty drums grouted and packaged. The process is current (no signtficant back log).

A disposal request has been submitted through PNL Safoguards for this material. No direction has yot been received. This goal has been carried over to CY 1991.

Work authorized, expected to be complete by $4 / 1 / 91$. This goal has been carried over to CY 1991.

Complete. This goal replaced a previously stated goal to remove high dose, rate-fixed contamination in concrete curbing back-side $325 \mathrm{~A}$ hot cells. 
Reaotor Technology 324 SMF
327 Postirradiation Test ing Laboratory

327 Postirradiation Testing Laboratory
Dispose of unused and/ar obsolete prooessing and test equipment currently stored in the SMF operating gallery. This equipment is potentially radtologically contaminated. and timely disposal will reduce the potential for personnel contamination and radiation exposure.

Remove and dispose of miscellaneous irradiated test specimens which are currently stored both in SMF East coll and SMF South cell. These specimens have no further exper 1 mental use, and their disposal will result in significant lower radiological exposure to SMF operating personnel during cell entries.

Reduce radiation exposure levels to personnel working in the area of the 327 Building $\mathrm{B} \mathrm{Cell}$ and $\mathrm{O} \mathrm{Ce} 11$ by cleaning ducts and/or drain line or adding additional steel shielding. This would reduce extremity dose rates to personnel by 50 to $75 \%$ in these areas.

Remove accumulated non-TRU radtoactive waste from 324 SMF and 327 Bullding hot cells. Prepare and ship waste to calsson burial. Continued removal of waste will result in lowered radiation exposure by $25 \%$ to both operations personne 1 and customers working at the various hot cells.

Cont inue to develop a suttable method and an approved procedure for cleaning the interior of the individual hot-cell ventilation ducts. Successful cleaning of these ducts will substantially reduce radiation zone levels in the 327 Buflding basement area by 50 to $75 \%$
Status

Approximately $90 \%$ of the unused or excess equipment prevlously stored in the SMF operating gallery has been excessed, transferred to the loan pool, returned to the proper equipment custodian, or disposed of as radioact ive waste. The remaining equipment items are being retained to support future tentatively scheduled in-cell examination programs.

Transfer of all remaining specimens containing Speolal Nuclear material to the 327 Buflding has been completed, leaving the SMF with no current inventory of SNM. Most of the remaining irradiated archive samples have either bean disposed of as radloact ive waste or transferred to 327 for interim storage. Disposition of the remaining samples wlll be determined based upon guidance from the appropriate experimenters.

Additional shielding was placed under the cell to reduce readings; this is an interim correction unt 11 the ducts' and drain lines' interfor surfaces can be decontaminated. Vendor information was reviowed and a purchase requisition for the purchase of a high pressure oleaner was initiated. Cleaning of ducts and/or drain lines w $\$ 11$ be carried over as a 1991 goal.

High-energy irradtated materlals are processed rapldly and stored or moved to areas that provide additional shielding before continuing with the processing of the low-energy materials. These actions have reduced the exposure levels at the hot cell operating station by a 5 to 1 ratio.

Awalting arrival of the high-pressure washer. Goal will be carried over as a 1991 goal 
Review ohemioal triventory and reduce where approprlate: cont inue updating faollity MSDS files and chemioal database and provide key state and federal Environmental Compllanoe schooling opportunit les for the Hazmat oustodian to assist with chemical control and disposal.

Earth and Environmental Sotences

Applied Phystos

Develop and implement a program for review of hazaruous waste generation activities which will encourage waste minimization, pollution control and reduction of cost ausoclated with waste disposal.

Review projeots to determine neoessity for chemical exposure monitoring. Implement eng ineering or protective clothing ountrols where necessary to remain below the permissible chemical exposure $1 \mathrm{imit}$.

Develop and fmplement a Laboratory information to the staff. Provide

Complete. Hazardous Materfal Custodian continues to revlew and reduve ohemioal inventory as appropriate. Management $P$ lan for the center.

The plan will oover safety, hazardous materials, securlty, the respons 1 bllities of all staff members, and will require the ident $\{$ flcation of the resources for plan imp lementation.

Laboratory quality and housekeeping inspections $w 111$ be performed on a bimonthly basis. The results of the inspections will be reviewed with departinent manayers.
A program has been established to perform the project revlews and evaluate the need for monitoring. Implementation of the program has begun and is a continual and ongoing task.

Plan developed and impleinented.

Inspections and reviews of inspection results have been performed. 
APPENDIX B

RADIOLOGICAL ALARA GOALS FOR CY 1991 


\section{APPENDIX B}

\section{RADIOLOGICAL ALARA GOALS FOR CY 1991}

Center/Dept.

Waste Technology 324

Laboratory

Safety 324

Materials and Chemical Sciences $306 \mathrm{~W}$
Goal

Reduce dose to hot-cell operations technicians by $20 \%$ from CY 1990 . This will be accomplished by reviewing dose reduction techniques, such as time, distance, and shielding at the pre-job ALARA meetings.

Reduce quantity of secondary waste products generated by programmatic activities by $50 \%$ frum CY 1990.

Reduce the number of skin contamination events of Waste Technology Center staff by $25 \%$ from CY 1990. This will be accomplished by reviewing, during the pre-job ALARA meetings, proper dressing/undressing techniques.

Improve pencil dosimeter program for RPTs assigned to the 324 facility. This program will allow the RP to more closely track RPT exposure as a function of work performed.

Continue to pursue the relocation or disposal of $\mathrm{ThO}_{2}$ located in Room 141 to reduce dose rate in Laboratory 151. A Material Request was submitted to Safeguards on $5 / 7 / 90$, but this CY 1990 goal was not completed since no disposition instructions were received.

Locate material storage and waste barrels for depleted uranium metal turnings in a central location within the specialty machine shop in Room 132. This location is to be, at a minimum, ten feet away from any equipment/ machinists' work station and will reduce background exposure to all program personnel. Previous storage areas were more convenient to both program machinists and the project's technical staff, but their random placements throughout the shop placed larger-thannecessary quantities of radioactive material next to the work stations. 
Modify to increase the physical size of the radiation area in Room 132 to allow for the transport of radioactive material from the heat treatment area in Room 152 to the specialty shop (Room 132). This would allow the large rol1-up door between the two bays to be opened to mure easily transport material to and from the material processing areas without the use of roller carts. Material will be loaded onto one cart, then moved directly to its next processing/machining station while remaining within a radiation area.

Materials and Chemical Sciences 325

Reactor Technology 324 SMF

Reduce the dose rate at the front face of the $325 \mathrm{~A}$ hot cells by providing adequate shielding in the face and ducts under the floor, and changing the filters on the ducts.

Reduce radiological exposure to personnel during radiochemical analysis of waste tank samples by implementing a recently developed analytical procedure for the analysis of transuranic elements in single she 11 tank and double she 11 tank samples. This procedure replaces four previously used procedures, thereby reducing considerably the total quantity of radioactive sample required. In addition, the period of time that staff members will be in contact with the sample during the analytical process has also been reduced. As funding permits, additional procedure development activities to reduce staff exposure will be undertaken.

Return cesium chloride capsule not needed for performance evaluation of cesium chloride encapsulation programs to the Waste Encapsulation and Storage Facility. Removal of the capsules will facilitate operation in both SMF South and East cells and reduce exposure risks to personnel.

Shield manipulator through tubes to reduce exposure to building occlipants. Shielding will effectively decrease exposure to acceptable levels. 
Center/Dept.

327
Convert Model $G$ and Model $E$ manipulator Z-motion tape to cable. The number of repairs/ replacements will be reduced, as will fewer change-outs, which will result in lower personnel exposure.

Clean the interior of $D$ and $F-C e l l s^{\prime}$ ventilation ducts. Successful cleaning of the ducts will reduce radiation levels in the basement area by 50 to $75 \%$.

Review 327 Post-Irradiation Testing Laboratory safe operating and technical procedures and revise, as necessary, to include requirements for preplanning meeting, ALARA meeting outline, and chemical/radiological ALARA information where applicable. 
APPENDIX C

PROJECTIONS FOR CY 1991 


\section{APPENDIX C}

\section{PROJECTIONS FOR CY 1991}

Projections for $c y 1991$ are 70 person-rem whole-body and 30 skin contamination cases. These projections are based upon planned work activities for CY 1991.

C. 1 
APPENDIX D

SKIN CONTAMINATION CASES DURING CY 1990 


\section{SKIN CONTAMINATION CASES DURING CY 1989}

\begin{tabular}{|c|c|c|c|c|c|c|}
\hline Date & $\begin{array}{l}\text { Orgini- } \\
\text { zation } \\
\text { Code } \\
\end{array}$ & Facility & Hoom & Cause & Affected Area & Comments \\
\hline $01 / 19 / 90$ & $792 B$ & 327 & Canyon & Person. Error & Finger Tips & $\begin{array}{l}\text { Took glove off to handle a } \\
\text { plece of metal to work on. }\end{array}$ \\
\hline $01 / 19 / 90$ & $792 B$ & 327 & Canyon & Unknown & $\begin{array}{l}\text { Skin area: } \\
\text { base of jaw }\end{array}$ & $\begin{array}{l}\text { Had contamination on } \\
\text { T-shirt. }\end{array}$ \\
\hline $03 / 14 / 90$ & 797.B & 324 & $\begin{array}{l}\text { Air Lock } \\
\text { Cask Area }\end{array}$ & Cloth. Fall. & $R$ Knee & $\begin{array}{l}\text { Implemented use of knee } \\
\text { pads, Samples of pants } \\
\text { revegled significant }{ }^{3} \mathrm{Cs} \\
\text { and } \mathrm{Sr} \text { contamination. }\end{array}$ \\
\hline $03 / 14 / 90$ & $791 B$ & 325 & 603 & $\begin{array}{l}\text { Contamination } \\
\text { on waste con- } \\
\text { tainer handle }\end{array}$ & $L$ Finger Tips & $\begin{array}{l}\text { Follow-up survey of area } \\
\text { revea led contamination on } \\
\text { waste container handle. }\end{array}$ \\
\hline$\emptyset 3 / 16 / 90$ & $792 B$ & 324 & 123 & Radon-natural & L palm & None. \\
\hline $04 / 05 / 90$ & $7 W 24$ & 324 & Greenhouse & Person. Error & Hair & $\begin{array}{l}\text { Rubbed head against inside } \\
\text { wall; not wearing head pro- } \\
\text { tection. }\end{array}$ \\
\hline $04 / 05 / 90$ & $793 \mathrm{~A}$ & 324 & 18 & Person. Error & Top of head & $\begin{array}{l}\text { Contaminated head while } \\
\text { directing workers to come } \\
\text { out of greenhouse. }\end{array}$ \\
\hline $05 / 31 / 90$ & 7E 41 & 314 & $H B 5 D$ & Unknown & Palms & $\begin{array}{l}\text { Possibly caused by handling } \\
\text { sample container. }\end{array}$ \\
\hline $06 / 15 / 9 \emptyset$ & $7 E 50$ & 325 & 309 & Unknown & Palms & None \\
\hline $97 / 62 / 90$ & 7EQ1 & 325 & 312 & Unknown & $R$ hand & $\begin{array}{l}\text { Involved in sink } \\
\text { decontamination. }\end{array}$ \\
\hline $07 / 25 / 90$ & $792 . B$ & 325 & Cask Handle & Cloth. Fail. & $\mathrm{R}$ arm & $\begin{array}{l}\text { Possible previous con- } \\
\text { tamination on coveralls. }\end{array}$ \\
\hline $07 / 25 / 90$ & $791 E$ & 325 & 32 & Unknown & $L$ thumib & None \\
\hline $67 / 27 / 90$ & $792 B$ & 324 & Air lock & Cloth. Fail. & L forearm & $\begin{array}{l}\text { Profuse sweat enhanced } \\
\text { clothing failure. }\end{array}$ \\
\hline $08 / 01 / 90$ & $7 W 25$ & 327 & Canyon & Person. Error & $\begin{array}{l}\text { Rear thigh, } \\
\text { calf and } \\
\text { nose. }\end{array}$ & $\begin{array}{l}\text { Broke a line into ce } 11 \text { and } \\
\text { over-pressured. }\end{array}$ \\
\hline $08 / 05 / 90$ & $7 W 23$ & 324 & A ir lock & Person. Error & L knee & $\begin{array}{l}\text { Plastic torn while working } \\
\text { in airlock. }\end{array}$ \\
\hline $08 / 08 / 90$ & 7932 & 331 & $\begin{array}{l}\text { SE Exit } 1 \text { st. } \\
\text { Fir }\end{array}$ & Unknown & Hands & None \\
\hline $08 / 15 / 90$ & 7928 & 327 & $\begin{array}{l}\text { Outside } \\
\text { Butlding }\end{array}$ & Unknown & $R$ palm & $\begin{array}{l}\text { Possibly caused by handling } \\
\text { air sampler probe. }\end{array}$ \\
\hline $08 / 22 / 90$ & $792 B$ & $306 \mathrm{~W}$ & 132 & Unknown & $\mathrm{R}$ pa $1 \mathrm{~m}$ & None \\
\hline
\end{tabular}

D. 1 


\begin{tabular}{|c|c|c|c|c|c|c|}
\hline Date & $\begin{array}{c}\text { Organi- } \\
\text { zation } \\
\text { Code } \\
\end{array}$ & Facllity & Room & Cause & Affected Area & Comnents \\
\hline $08 / 28 / 90$ & $7 C 18$ & 325 & 517 & Unknown & $\begin{array}{c}\text { Fingers, } L \\
\text { hand }\end{array}$ & $\begin{array}{l}\text { Working with }{ }^{99} \text { Tc instde } \\
\text { hood. }\end{array}$ \\
\hline $09 / 13 / 90$ & $792 \mathrm{~B}$ & 324 & B Gallery & Person. Error & $L$ thumb & $\begin{array}{l}\text { Falled co contact RPT } \\
\text { before start. }\end{array}$ \\
\hline $09 / 24 / 90$ & $792 B$ & 325 & 711 Fan Rm & Unknown & L palm & $\begin{array}{l}\text { Suspect radon decay } \\
\text { products. }\end{array}$ \\
\hline $10 / 23 / 90$ & $793 \mathrm{~A}$ & 324 & SMF Gallery & Person. Error & L palm & $\begin{array}{l}\text { Cross-contamination whtle } \\
\text { surveying and while } \\
\text { undressing. }\end{array}$ \\
\hline $10 / 23 / 90$ & $7 R 32$ & 324 & Decon Rm. & Person. Error & $\begin{array}{l}R \text { eye, nose, } \\
\text { upper lip. } \\
R \text { thumb }\end{array}$ & Procedural problems. \\
\hline $10 / 23 / 90$ & $792 B$ & 324 & 139 & $\begin{array}{c}\text { Contamination } \\
\text { Door Handle }\end{array}$ & L palm & $\begin{array}{l}\text { Hand le poss tbly con. } \\
\text { taminated from egress of } \\
\text { SMF after contaminants were } \\
\text { spread in area. }\end{array}$ \\
\hline $10 / 23 / 90$ & $7 W 25$ & 324 & Decon Rm & Person. Error & Hair and nose & Procedural problems. \\
\hline $10 / 23 / 90$ & $7 R 31$ & EDF & Lab & Unknown & Nose & None. \\
\hline $11 / 16 / 91$ & 7928 & 324 & $\begin{array}{l}\text { B-Cell } \\
\text { Airlock }\end{array}$ & Unknown & Neck & $\begin{array}{l}\text { Possibly contaminated while } \\
\text { undressing. }\end{array}$ \\
\hline $11 / 29 / 99$ & 792.8 & 324 & Change & Cloth. Fail. & $L$ wrist & $\begin{array}{l}\text { Profuse sweat contributed } \\
\text { to contamination. }\end{array}$ \\
\hline $12 / 4 / 90$ & 7933 & 324 & Change & Unknown & $\begin{array}{l}\text { R middle } \\
\text { finger }\end{array}$ & $\begin{array}{l}\text { Possible mishandling of } \\
\text { stack monitor check source. }\end{array}$ \\
\hline $12 / 12 / 90$ & $7 E 15$ & 325 & 400 & Person. & $\begin{array}{l}L \text { hand } \\
\text { fingers }\end{array}$ & $\begin{array}{l}\text { Reached in hood to move } \\
\text { equipment while not wearing } \\
\text { glove. }\end{array}$ \\
\hline $12 / 20 / 90$ & $7 E 15$ & 325 & 400 & Person. & $\begin{array}{c}\text { Forearms and } \\
\text { fingers }\end{array}$ & $\begin{array}{l}\text { Contamination from lab coat } \\
\text { was transferred to arms } \\
\text { while removing coat. }\end{array}$ \\
\hline
\end{tabular}

D. 2 


\section{DISTRIBUTION}

No. of

Copies

\section{OFFSITE}

12 DOE/Office of Scientific and Technical Information

\section{ONSITE}

DOE Richland Field office

Hanford Environmental Health Foundation.

M. A. Mckinney, H1-53

Westinghouse Hanford Company

J. F. Dickman (5), so-15

\section{Pacific Northwest Laboratory}

83 R. C. Adams, K6-52

W. J. Bair, K1-50

W. J. Bjorkiund, P7-68

J. D. Bright, P7-08

D. S. Broussard, K1-67

D. P. Carlisle, P7-74

G. M. Ceffalo (5), P7-78

R. L. Cheatham, K7-10

T. D. Chikalla, P7--75

T. T. Claudson, B1-40

G. H. Cunningham, K1-59

R. L. Dodd

J. W. Falco, K6-78

A. M. Fillion, P7-78

M. D. Freshley, K6-77
No. of

Copies

M. F. G117is, K1-50

M. J. Graham, K6 -80

J. M. Hales, K6-04

R. J. Hall, K1-73

P. E. Hart, K7-02

M. A. Hensye1, P7-78

D. P. Higby (20), P7-78

T. Hikido, P7-70

J. M. Hobbs, P7-78

G. R. Hoenes, P7-78

J. N. Holloway, K1-36

J. R. Houston, A3-60

B. M. Johnson, K1-78

J. R. Johnson, K3-53

A. F. Johnston, K1.44

E. L. Kelley, K6-78

R. R. King, P7 -70

M. L. Knotek, K1-48

D. E. Knowlton, P7-40

W. W. Laity, K2-50

L. M. Martucci, P7-35

J. L. MCETroy, P7-46

G. L. McVay, K2-45

C. L. Oxley (5), P7-78

B. D. Robertson, P8-01

J.T.A. Roberts, K1-73

D. A. Seaver, K6-61

B. D. Shipp, K1 $\cdots 3$

R. L. Skaggs, K6-77

T. S. Tenforde, K1.50

M. T. Thomas, K2-12

R. E. Witdung, P7-54

W. R. Wiley, K1-46

G. L. Work, K7-0?

P. A. Wright, P7 78

Publishing Coordination

Technical Report Files (5) 

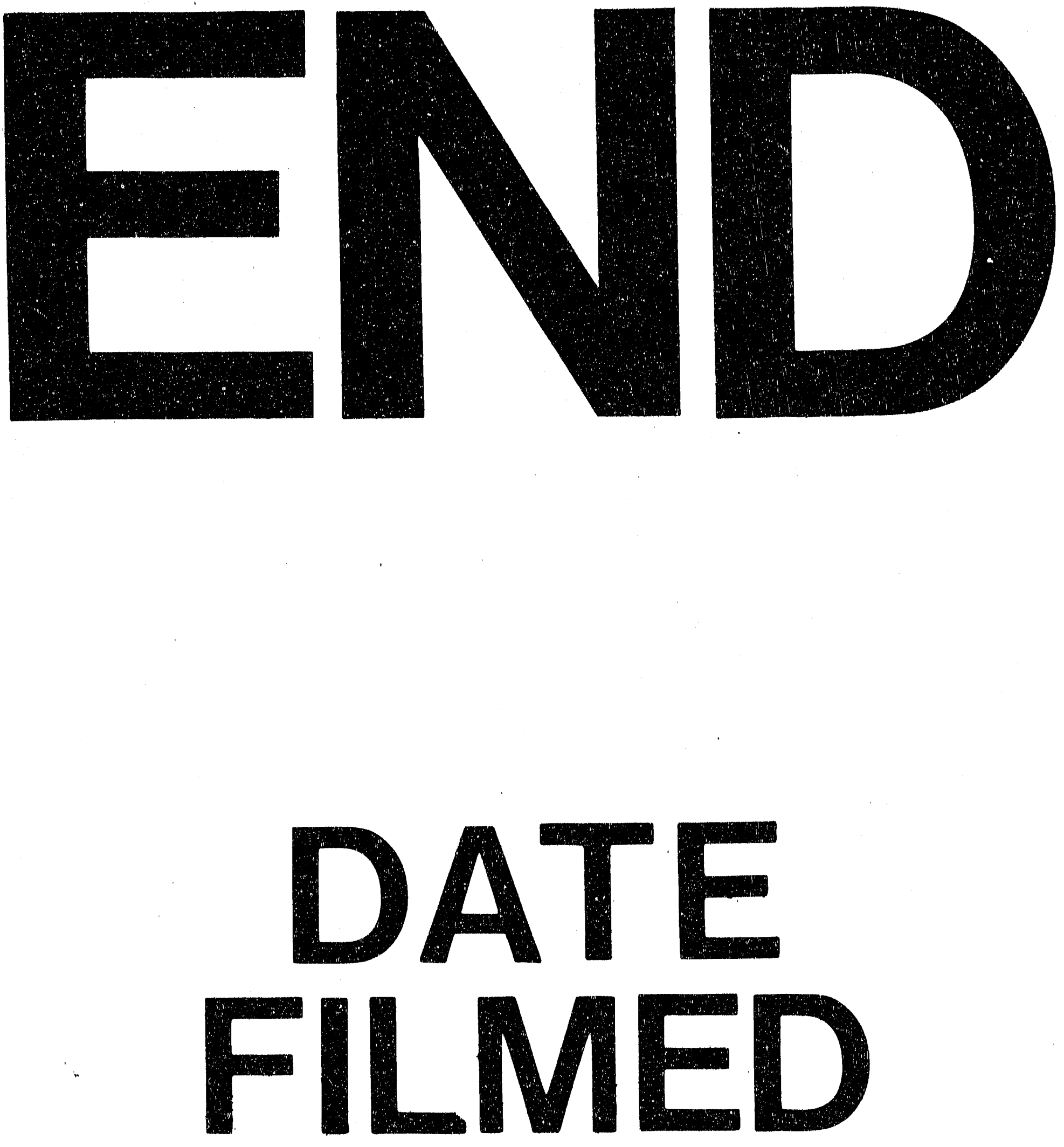

|

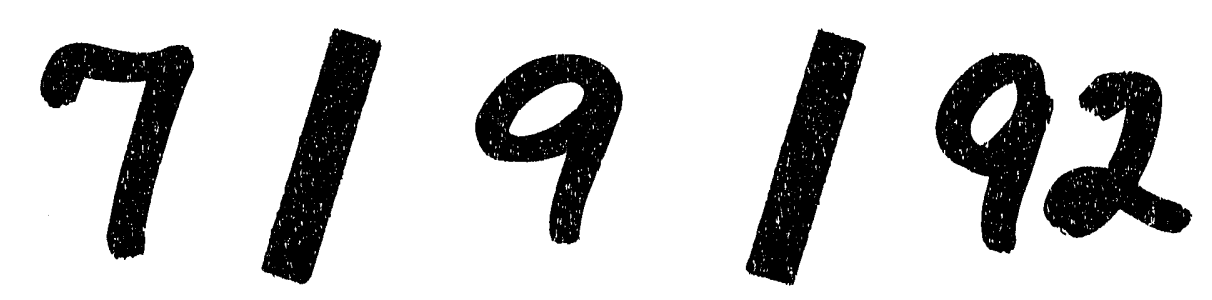


